\title{
The Use of the Volatility of Futures Contracts for the Construction of an Investment Strategy
}

\author{
Rafał Balina, Sławomir Juszczyk, Marta Idasz-Balina \\ Warsaw University of Life Sciences, Warsaw, Poland
}

\begin{abstract}
This paper presents an overview of the literature on capital market anomalies and demonstrated the existence of anomalies in the distribution of rates of return in relation to trading wheat futures. The study was based on the real trading data wheat futures. The data come from two periods. The first periods consisted quotations of wheat futures from 1 January 2010 to 31 December 2011. The second period from 1 January 2011 to 30 June 2011, which served as an assessment of the effectiveness of constructed investment strategy. On the basis of analysis data from the first period was noted that the rate of return and the coefficient of variation for wheat futures in the last four hours of the day of trading are significantly higher than in the early hours. Based on the reported anomalies the authors show the capability of their use to design an investment strategy that generates outstanding profits. On the basis of the analysis it was noted that in the case of wheat futures prices they reach their highest level of variation between the hours of 04:35 PM and 07:35 PM each day, which has a decisive influence on the daily rate of return. In addition, rates of return from taking a position before 12:35 PM and keeping it in the second trading period gave significantly better results than closing it before 04:35 PM. This phenomenon can be considered as an example of anomalies of futures market for agricultural products. Also the result of the author's research can be used to predict price movements of wheat futures.
\end{abstract}

Keywords: wheat futures, rate of returns, anomalies, capital market, investment strategy, Fibonacci ratios

\section{Introduction}

\section{Overview of the Literature on Capital Market Anomalies}

Analyzing the literature associated with investing in financial markets can be found statement that in order to make the right investment decisions and make the investment generate above average returns with an acceptable level of risk, you must have knowledge of the functioning of financial markets; the subject of the transaction; tools and methods; technical analysis of the market and broadly defined financially (Szwager, 1992; Pring, 1995; Paulos, 2003).

On the capital market as knowledge can be regarded as an investment strategy, which should be based on processed market data which allows for the effective management of invested capital. However, in the literature on the equity markets, you can often find research presenting only information which is the result of processing

Rafał Balina, Ph.D., Faculty of Economic Sciences, Warsaw University of Life Sciences.

Sławomir Juszczyk, Professor, WULS dr. hab, Faculty of Economic Sciences, Warsaw University of Life Sciences.

Marta Idasz-Balina, MSc, Faculty of Econimic Sciences, Warsaw University of Life Sciences.

Correspondence concerning this article should be addressed to Rafał Balina, Warsaw University of Life Sciences-SGGW, Faculty of Economic Sciences, 166 Nowoursynowska Str., 02-787 Warsaw, Poland. E-mail: rafal_balina@sggw.pl. 
the data with no clear indication of the application in the economy (Danielewicz, 2006).

Examples of information regarding the capital market are anomalies in the distribution of rates of return which allow you to predict the behavior of asset quotations using the study of its historical trading. Studies carried out in this field had made many researchers including: Fama (1991), Haugen and Lakonishok (1988), Dimision (1988), M. N. Glutekin and N. B. Glutekin (1986), Reinganm (1983), Ariel (1987), French (1980), Keim and Stambaugh (1985), Rogalski (1984), and Smirlock and Starks (1986). The results of their research indicate that a diverse distribution of rates of return on shares over the analyzed period - month, week, day, hour or even minute. However, in these studies, there is no indication of their practical application in order to make investment decisions.

\section{The Notion of Investment Strategy}

In the literature of the subject many definitions of a strategy can be found. For instance, Griffin (1998) described a strategy as a general plan including decisions concerning resource allocation, priorities and actions necessary to achieve strategic goals. According to Kotler (2005), a strategy is a plan of a game, which enables to achieve the previously set aims. In contrast, Drucker (1954) perceived a strategy as an activity in which one analyses the current situation and changes it if it is necessary. In the military context, a strategy is an art of distribution and usage of military resources (Liddell Hart, 1959).

In the capital market theory, an investment strategy is a pattern of repeated behaviors of purchase, sale or expectations concerning decision-making on the financial market (Murphy, 1999). Another definition of an investment strategy was proposed by Tramp (2000). According to him, an investment strategy is a way of acting on the financial market, thanks to which an investor is going to realize one's purchase and sale orders of a determined stock on a given segment of the capital market. Instead, according to Okrojek (2001), an investment strategy is making use of a technical analysis in order to indicate the moment of entering and exiting a position.

Many examples describing and defining an investment strategy can be given, but regardless of the area it refers to, one can state that it is a group of norms and rules of conduct in situations circumscribed by this investment strategy. Very important is what comprises in an investment strategy. Each investor has an individual system of values, on the basis of which he or she develops a strategy enabling to make transactions on the capital market at such a risk level that is acceptable by him or her. However, despite individual features and predispositions, investment strategies consist of many common elements. Firstly, an appropriately built investment strategy should clearly and precisely determine the moments of entering and exiting a position. Additionally, the strategy should include an element which determines the rules of setting STOP-LOSS orders-A moment which gives a signal that an investor has made a mistake and should retreat from an investment. Another element that is necessary for the investment strategy to be efficient is the capital control. The investment strategy should make it possible to determine whether prices will follow the investor's expectations after opening a position in a market and whether the investor will have chances to make up for possible losses.

Constructing an investment strategy is a complex process that consists of several phases, which strongly influence each other. This process is mainly based on information. That is why it is so important for an investor to have reliable information. Most often, before starting to gather information, an investor chooses one of the approaches in which the strategy will be built. He/she can choose a fundamental analysis, basing on the 
analysis of economic and political condition of a country and companies which he/she is interested in, or a technical analysis that is an analysis of stock price volatility (Pachota, 1994).

The first stage of investment strategy building is gathering the information about the previously chosen approach. Then, basing on the acquired information, one should formulate a general opinion about a given stock. As a next step, the opinion should be verified in the view of the newest information from the market, taking also into account the opinion of specialists and one's own knowledge. If the information acquired through the fundamental or technical analysis, or combination of both approaches, is confirmed by the market, the investor makes a decision about opening or closing a position. In case when the investor's analyses are not confirmed, no actions concerning making a decision about a transaction are made.

Independent of the characteristic of a market which an investor acts on, the investment strategy and the process of its constructing should consist of three stages (Tramp, 2000):

- Setting investment goals;

- Working on a system;

- Measuring and evaluation of the results.

It is not by chance that setting investment goals is the first element of the strategy construction. It is most important because it determines the next stages of investment strategy building. What should be set at this stage is an expected annual rate of return, maximal risk level, and maximal acceptable capital loss. Setting these elements appropriately enables to check the effectiveness of the constructed investment strategy as well as to determine the level of initial capital, which is necessary for goals' realization.

The work on the system consists of several elements. The first one is the review of one's own possibilities because in order to build a system that is supposed to be successful, it must be appropriate for its user. The second element, which is necessary in working on a system, is gathering information about the market on which an investor will act. After getting to know the market, one should set investment goals again or verify the previously defined ones according to a given market and its characteristic. Then, a time perspective should be determined. It means how long the investor is going to be on the market and whether he would like to invest in a short- or long-term perspective. Another important element is to find in historical data the moments in which stock prices significantly changed and to analyze the similarities as well as differences between them. Then, basing on ratio analysis and charts, the investor should find formations on the chart or the patterns of indicators, which give information about current price movement, so that it can be used for one's own goals in the future. At this stage, basing on historical data and situations that occurred in previous time periods as well as using information and skills, detailed rules of opening and closing a position on a given market are set. After getting to know the premises to take a position, a so-called STOP-LOSS line should be set. The STOP-LOSS line has the aim to determine the maximal loss that an investor can incur or, a crucial thing, a profit level that is satisfying enough for an investor.

The final stage of the investment strategy building is determining the rules of profit realization and measuring the effectiveness of the system. Basing on the results of this stage, the usefulness of the system is verified and decisions about its modifications are made so that it can be more efficient and bring even more profits.

The measurement and evaluation of results are done by calculating the profit or loss brought by application of this investment strategy. Only the last stage gives an investor an answer to the question whether 
the goal set has been realized or whether the strategy should be changed into a more effective one.

\section{Purpose and Methods}

The main objective of this paper is to demonstrate the existence of significant differences in the volatility of wheat listed on the FOREX market during the hours of 04:35 PM-07:35 PM compared with the quotation from 01:35 AM-12:35 PM, as an anomaly in the futures market for agricultural products and presenting the author's investment strategy connected with wheat futures listed on the FOREX market.

The study was based on the real trading data wheat futures from two periods. The first periods consisted quotations of wheat futures from 01 January 2010 to 31 December 2011. In total, the first period consisted of 253 days, during these days trade of wheat futures took place. Due to the fact that trading in wheat futures took place from 1:35 AM-07:35 PM and that during the hours between 01:35 PM and 03:35 PM, the trade was small and the quotations from those hours were excluded from the study. As a result of the above findings, the study of the first period was based on a sample of 4,048 hourly quotations on wheat futures. Data from the first period were used to identify differences in the quotations of futures exchange in the morning, it is 1:35 AM to 00:35 PM and 04:35 PM-07:35 PM.

Rate of return in particular hours refers to changes daily so therefore a one hour and 35 minutes will always be $0 \%$. This presentation will illustrate in an easy way how it will change the rate of return depending on the duration of a given position in the market. The second period from 1 January 2011 to 30 June 2011, served as an assessment of the effectiveness of constructed investment strategy.

Modified values of Fibonacci coefficients were used to draw price projections for the analyzed stock. Fibonacci retracements have shown moments of entering the market and market exits. All graphs in the article were done using Japanese candlesticks in order to depict the changes in wheat futures prices as precise as it is possible.

\section{Results of Research}

\section{Anomalies in the Distribution of Rates of Return of Wheat Futures}

Study period includes periods in which followed an increase, decrease, and consolidation quotes. Analyzing the quotes of wheat futures on an hourly arrangement may notice a pattern. Namely, listing the hours 4:30 PM to 7:35 PM had a significantly higher quotation than it had placed in the hours before the hours 00:35 PM - a graphical presentation of the above observations is shown in Figure 1.

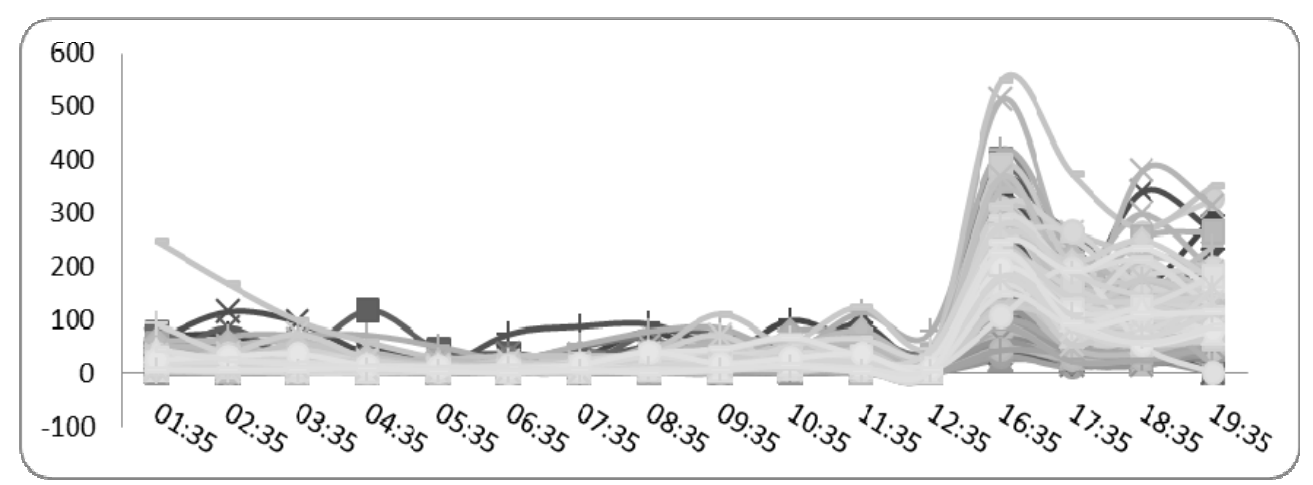

Figure 1. Fluctuations of price of wheat futures on an hourly arrangement (PLN). 
In order to confirm the observed dependence later was used following formula for rate of return for long position of wheat futures:

$$
R_{t}=\frac{P_{t}-P_{0}}{P_{0}}
$$

where:

$R_{t}$ : the rate of return in a given time;

$P_{t}$ : closing price at the time;

$P_{0}$ : the closing price in the first hour of trading.

Rates of return in individual hours are related to daily changes. This assumption illustrates the rate of return will change depending on the time to maintain a market position. The rates of return calculated by the above formula are shown in Figure 3. Analyzing Figure 2 should be emphasized that the rates of return during hours from 1:35 AM-12:35 PM are relatively stable and range from $-2.9 \%$ to $5.44 \%$.

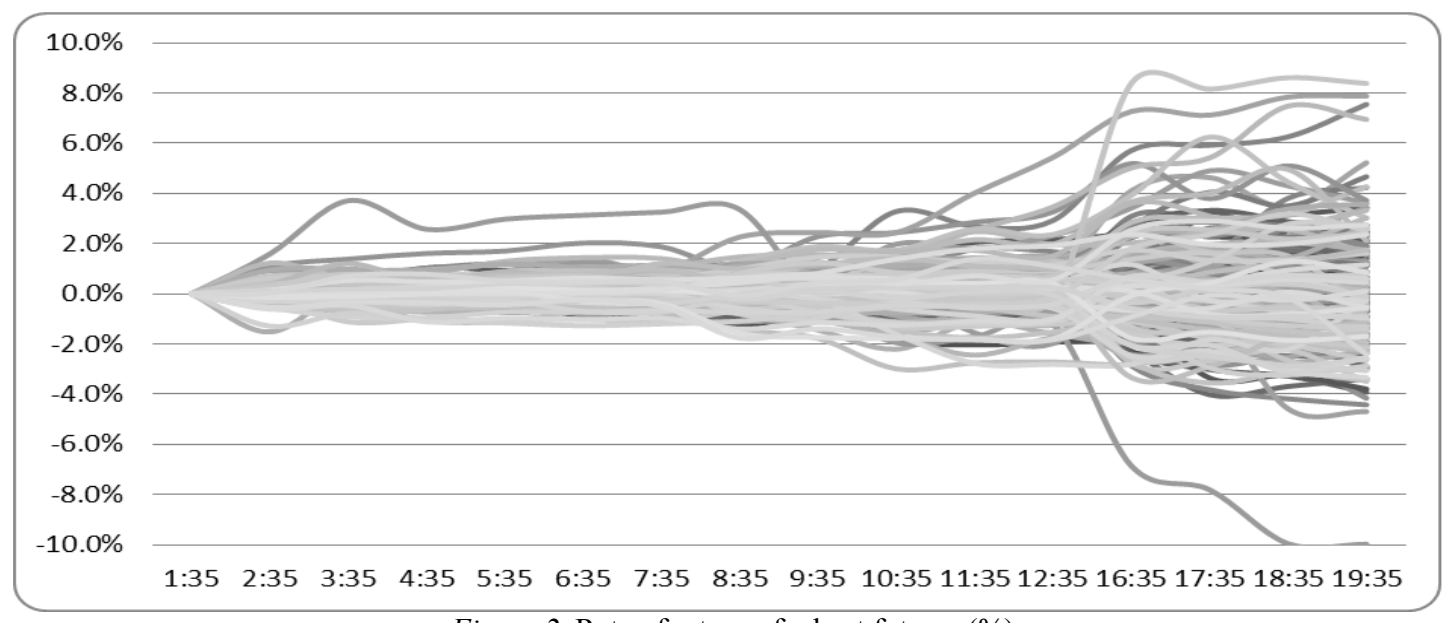

Figure 2. Rate of return of wheat futures (\%).

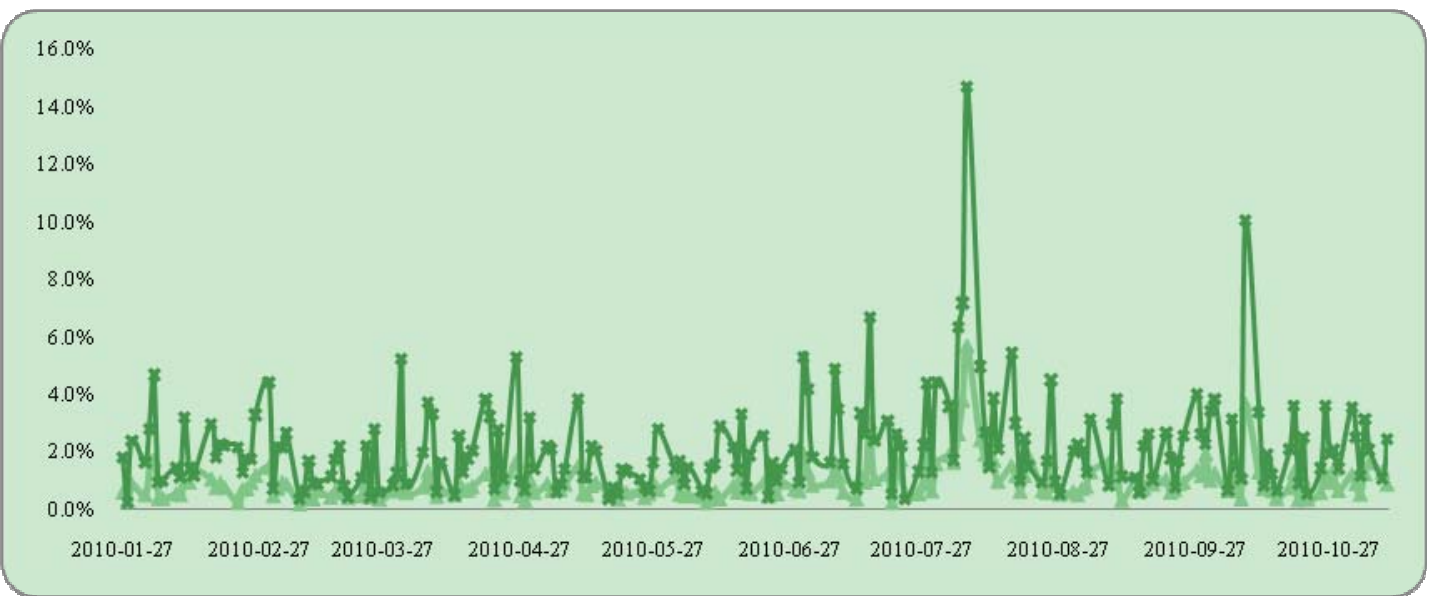

Figure 3. Coefficients of variation in each group (\%).

Their levels should be considered as relatively low, obtained yields because after taking into account transaction spared do not allow obtaining extraordinary results that an investor would reach. During hours between 04:35 PM and 07:35 PM rate of return had significantly higher values than the rates of return obtained 
in the hours of 01:35 AM and 12:35 PM. Namely, these changes ranged from $-9.98 \%$ to $8.61 \%$. From the perspective of an investor opening positions in the first hour of trading wheat futures on a given day and keeping it until the afternoon that same day gave the opportunity to gain a higher rate of return because the range of variability in the rate of return was much higher than in the morning.

In order to indicate differences in volatility between periods the coefficient of variation was used as a statistical measure to determine the scope of changes allowing trading wheat futures in periods. The following formula was used for the calculation (Sobczyk, 2006, p. 46; Witkowska, 1999, p. 90):

$$
V=\frac{\sqrt{\frac{\sum_{i=1}^{n}\left(x_{i}-\bar{x}\right)^{2}}{n}}}{\bar{x}}
$$

where:

$V$ : coefficient of variation;

$n$ : number of observations;

$x_{i}$ : value of the $i$-th observation.

$$
\bar{x}=\frac{\sum_{i=1}^{n} x_{i}}{n}
$$

The object of this research was divided into two groups according to the previously observed decay rates of return. The first group consisted of observations from the period between the hours of 01:35 AM and 12:35 PM, and the second group consisted of observations from 04:35 PM to 07:35 PM. The coefficient of variation was calculated for each group. The obtained results are shown in Figure 3.

The study showed that the coefficient of variation calculated for the first group was in the case of 234 days of observation higher than in the second group. For other 19 cases the coefficient of variation calculated was lower than in the first group. This means that the variability between the hours of 01:35 AM and 12:35 PM was lower than that between 04:35 PM and 07:35 PM in 92.5\% of cases. The coefficient of variation in the first trading period ranged from 0.2 to $5.7 \%$ and in the second period ranged from $0.1 \%$ to $14.7 \%$. Clearly, it demonstrates the significant differences between the extent of variation between the quotations of wheat futures in hours between 01:35 $\mathrm{AM}$ and 12:35 PM and quotations from 04:35 PM to 07:35 PM. It should be noted that the biggest changes in the wheat futures prices took place during the period from 04:35 PM to 07:35 PM.

\section{Construction an Investment Strategy}

Characteristic of futures is that you can make money trading both on the increases and dips, which means that the benefits of investing in the futures market may be larger than the stock market (Zalewski, 2001). Therefore, it seems reasonable to construct an investment strategy which will use these relationships. Its construction, in addition to candlestick charts (Nison, 2001) and pointed timing, used Fibonacci coefficient, which was used to determine the moments of opening and closing positions. Their use is justified because, as research shows can be successfully used to predict the Fibonacci retracement formation of trading futures contracts on wheat consumption (Banasiak, 2010). In the literature concerning Fibonacci sequence theory, most common ratios are $0.382,0.618,1.382,1.618,2.382$, and 2.618 . They are derived by dividing each other the numbers that follow one another in the Fibonacci sequence (Hartle, 1997; Fisher, 1996). However, in the 
following part of the elaboration, modified values of the aforementioned ratios, presented in the work of Jim Kane, were used. Basing on the observations, he has noticed that often the prices of stock listed on capital markets oscillate around the highs indicated by classical values of Fibonacci retracements. In this study, modified Fibonacci ratios were presented for the first time by Jim Kane (2003). Selected coefficients are 0.886, $1.130,1.460,1.902$, and 2.058 .

Ratios of 0.886 and 1.113 values will be the levels beyond which the investor should withdraw from the position in order to limit losses. Level of 1.460 will be a moment in which investors should take a position depending on the direction of change, while the remaining values will be determined by the value of the rate at which investors should exit a position to realize a profit. Levels above which the investor should realize profits depend on the individual investor's risk propensity. Therefore, the authors suggest only two levels that can be considered safe, but investors may take different levels of take profit. Figure 4 shows an example of the application of Fibonacci ratios proposed for the futures contract for wheat consumption.

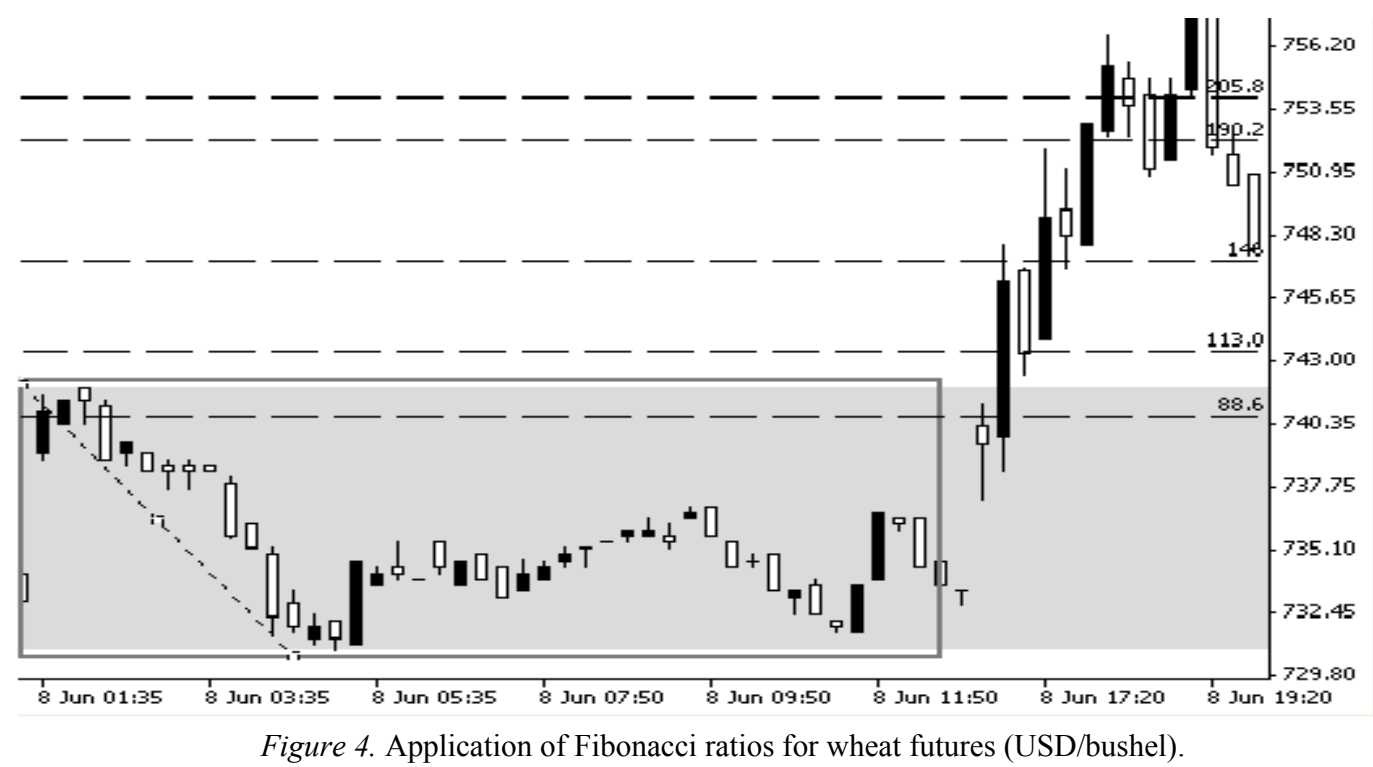

Fibonacci ratios (in the graph marked by horizontal dashed lines) were determined on the basis the test trading range between the hours of 01:35 AM to 12:35 PM. They allow you to determine the price projection, which will be the basis for decision-making. The authors recommend that to take positions followed after crossing the 1.460 ratio. This level allows you to open positions, as breakout of the channel formed by the quotations in the morning is strong and will likely continue. The use of this level also prevents the elimination of take a position too early because the 1.130 level is too low and the abolition of the trading asset breakdown can be regarded as accidental. Opening a position in such a situation could lead to loss to the investor.

\section{Assessment of the Effectiveness of the Investment Strategy}

The study on the effectiveness of the proposed moment of opening position, in the period from 01 January 2011 to 30 June 2011, shows that in 63 cases opening positions on the basis of projected price of the Fibonacci ratio 1.430 direction of breaking from the morning period was continued - due to the profits generated foothold. For 26 days of observation, this level has not been exceeded - so it was generated signal to take a position, 
which did not cause either losses or profit for investors, as he/she remained out of the market. For the remaining 11 observations suggested level position opening losses would occur. The results show the effectiveness of the proposed system, since only in the case of 11, they suggested the decision was wrong. The loss suffered by the investor would not be high because the level of stop loss was set at $88.6 \%$ from span trading hours of the morning. Thus, the maximum loss could amount to $11.4 \%$ of invested capital.

To complete the strategy was also to determine the moments take profits. The research shows that it is appropriate that the investor held the position until the rate reaches contract Fibonacci retracement level of 190.2\%. In the case of 55 indications to take a position on the market in all of these trading traffic continued until the abolition of the indicated level, after which followed the collapse of the movement and exposing the investor to reduce profit.

\section{Conclusions}

Basing on the conducted research, it can be stated that wheat futures prices reach the highest volatility level in time period between 04:35 PM and 07:35 PM on a given day, which has a decisive influence on daily rate of return. Knowledge concerning functioning of financial markets, which is gathered information and the abilities of using it in real circumstances, might give an investor a chance to gain profits from the transactions made. The conducted studies have shown that wheat futures price volatility in combination with Fibonacci coefficients may be the basis for constructing an effective investment strategy. Making use of the results enables to successfully enlarge capital on futures market due to satisfactory effectiveness of the constructed investment strategy. Additional advantage of the strategy is a possibility of its application in the present situation of the stock market. Among others, it will enable risk mitigation.

In practice, it is impossible to limit the risk on capital market entirely. However, from a mathematical point of view, using an investment strategy in a process of making decisions on capital market enables to get considerably better results than in case of not using it. This is due to the fact that while playing the stock market, the sum of wins is bigger than the sum of losses and the levels of investment risk are different, and the bigger it is, the bigger profits can be gained. The author has proved that the indicated relationships can be used in the process of constructing the investment strategy that will enlarge and protect the invested capital as well as limit the risk associated with investing on capital market. Moreover, it should be noticed that even the very precise way of following the investment strategy cannot eliminate the investment risk entirely. However, it can lead to its considerable decrease. That is why an investor should continuously control the level of risk-taking and check if it does not exceed the one assumed in the strategy.

\section{References}

Ariel, R. A. (1987). Monthly effect in stock returns. Journal of Financial Economics, 18(1), 161-174.

Balina, R. (2011). Selected aspects of investment decision making in the capital market (Wybrane aspekty podejmowania decyzji inwestycyjnych na rynku kapitałowym). Entrepreneurship and Management (Przedsiębiorczość i Zarzqdzanie), XII(6), 356.

Banasiak, K. (2010). The use of selectedtools of technicalanalysis in forecastingfuturesprices for wheat (Zastosowanie wybranych narzędzi analizy technicznej w prognozowaniu cen kontraktów terminowych na pszenice) (pp. 147-157). Warszawa: Wydawnictwo SGGW.

Danielewicz, P. (2006). The Fibonacci geometry-Practical course of investing in the financial markets (Geometria fibonacciego - Praktyczny kurs inwestowania na rynkach finansowych). Warszawa: Wydawnictwo WIG Press.

Dimision, E. (1988). Stock market anomalies. Cambridge: Cambridge University Press.

Drucker, P. F. (1954). The practice of management. New York: Harper \& Row Publishers Inc..

Fama, E. (1991). Efficient capital markets II. Journal of Finance, 5, 1575-1617. 
Fisher, R. (1996). Fibonacci numbers in the stock market (Liczby fibonacciego na gietdzie). Warszawa: Wydawnictwo WIG Press.

French, K. R. (1980). Stock returns for the weekend effect in stock returns. Journal of Finance, 8(1), 55-69.

Glutekin, M. N., \& Glutekin, N. B. (1986). Stock market seasonality: International evidence. Journal of Financial Economics, $12(4), 469-481$.

Griffin, R. W. (1998). Basics of firms management (Podstawy zarzqdzania organizacjami). Warszawa: Wydawnictwo Naukowe PWN.

Harris, L. (1986). A transaction data study of weekly and intradaily patterns in stock returns. Journal of Finance, 16, 99-117.

Hartle, T. (1997). Using Fibonacci ratios and momentum. Technical Analysis of Stocks \& Commodities, 15(1), 477-482.

Haugen, R. A., \& Lakonishok, J. (1988). The incredible January effect. Homewood, I.L.: Dow Jones-Irwin.

Kane, J. (2003). Advanced Fibonacci trading concept. Aberdeen: Kane Trading.

Keim, D. K., \& Stambaugh, R. F. (1985). A further investigation of the weekend effect in stock returns. Journal of Finance, 39(3), 569-572.

Kotler, P. (2005). Marketing. Poznań: Dom Wydawniczy REBIS.

Liddell Hart, B. H. (1959). Strategy: The indirectaction (Strategia: Działanie pośrednie). Warszawa: Wydawnictwo Ministerstwa Obrony Narodowej.

Murphy, J. J. (1999). Technical analysis (Analiza techniczna). Warszawa: Wydawnictwo WIG Press.

Nison, S. (2001). Japanese candlestick charting techniques. New York: New York Institute of Finance.

Okrojek, M. (2001). Money management na rynku walutowym. Magazyn Forward, 8, 18.

Pachota, J. (1994). A fortune in waiting in the stock market-What every player should know (Fortuna czeka na gieldzie czyli co każdy gracz wiedzieć powinien). Wrocław: Wydawnictwo CROM.

Paulos, J. A. (2003). A mathematician plays the stock market. New York: Basic Books Inc..

Pring, M. J. (1995). Investment psychology explained —Classic strategies to beat the market (pp. 4-7). New York: John Wiley \& Sons Inc.

Reinganm, M. R. (1983). The anomalous stock market behavior of small firms in January. Journal of Financial Economics, 12(1), 256-365.

Rogalski, R. J. (1984). New findings regarding day-of-the-week returns over trading and non-trading periods. Journal of Finance, 39(5), 1603-1614.

Smirlock, M., \& Starks, L. (1986). Day-of-the-week and intraday effects in stock returns. Journal of Financial Economics, 17, 197-210.

Sobczyk, M. (2006). Practical and theoretical aspects of statistics (Statystyka aspekty praktyczne i teoretyczne) (p. 46). Toruń: Wydawnictwo Uniwersytetu Marii Curie-Skłodowskiej.

Szwager, J. D. (1992). The new market wizards—Conversations with America's top traders. New York: Harper-Coltins Publishers Inc..

Szyszka, A. (1999). The efficiency of the capital market and the anomalies in the distribution of rate of return (Efektywnośćrynkukapitałowego a anomalie w rozkładziestópzwrotu w czasie) (pp. 25-31). Warszawa: Nasz Rynek.

Tramp, K. (2000). Market, freedom and money_Speculator guide (Giełda wolność i pieniadze_Poradnik spekulanta) (pp. 35-100). Warszawa: Wydawnictwo WIG Press.

Witkowska, D. (1999). Statistical methods in the management (Metody statystyczne w zarzadzaniu) (p. 90). Łódź: Wydawnictwo Uniwersytetu Łódzkiego.

Zalewski, G. (2001). Futures in practice (Kontrakty terminowe w praktyce) (pp. 4-5). Warszawa: Wydawnictwo SURS.NET. 